\title{
4. Internet under threat? The politics of online censorship in the Pacific Islands
}

\begin{abstract}
In the Pacific, there have been disconcerting news releases of governments making attempts at censoring the internet, a move seen to point towards silencing dissenting views on popular online forums. The conflicting trends between the new political forum ushered in by the new media on the one hand, and the restrictive mode of state censorship on the other hand, pose severe challenges to the broader framework of rights and freedom of expressions. This article aims to examine the regulatory approaches being developed and proposed in response to the emergence of new media in $\mathrm{Pa}-$ cific Island Countries (PICs). This article reviews two ways in which Pacific Island governments are attempting to regulate the internet, firstly through the development of legislation to prosecute cybercriminals, and secondly through the banning of specific internet sites, most notably Facebook. Despite the disparities in internet penetration levels, the article reveals that nearly all countries in the Pacific are increasingly regulating or are moving towards regulating the internet. The justifications for internet regulation and censorship are primarily predicated around the rhetoric of protecting its citizens from the adverse effects of the Internet. However, these regulations seem to be a response to Pacific Island governments' fears of growing criticism and political dissent on social media platforms.
\end{abstract}

Keywords: cyberbullying, e-democracy, ICT policy, internet censorship, media freedom, Pacific Islands, social media

\section{ROMITESH KANT}

La Trobe University, Melbourne

JASON TITIFANUE, JOPE TARAI and GLENN FINAU

The University of the South Pacific, Suva

\section{Introduction}

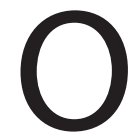

VER the past decade, and particularly in the last few years, the influence of the internet as a means to spread information and challenge government-imposed media controls has steadily expanded in the Pacific. Politicians and government agencies frequently find themselves the target of criticism on social media (Singh, 2015). This mounting influence directly correlates to the growth in the number of users throughout the Pacific Islands: 
approximately seven million people have access to the internet, and the figure has more than doubled in the past five years (see Table 1). However, as more people use the internet to communicate, obtain information, socialise and conduct commerce, governments globally are stepping up efforts to regulate, and in some instances tightly control, this new medium.

The internet brings about significant challenges regarding how monolithic institutions such as governments can adequately regulate such a rapidly evolving technology (Warf, 2011). These challenges include determining which part of the Internet to regulate, for instance, which websites, social media sites or content should be regulated or filtered. Another challenge is what should be regulated? What is considered an inappropriate use of the internet? Is, for instance, the criticism of the government on social media regarded as improper use of the internet? These are ethical problems that governments have to face, but issues that if not given due deliberation could lead to governments abusing their authority and the curtailment of freedom of expression on the internet.

The rise in social media usage in the Pacific has led to many cases of cyberharassment, cyberbullying and defamation (Nisha \& Farik 2015). Facebook pages and Facebook groups have sprung up where users expose marital affairs, corrupt individuals, and, what is most common, corrupt politicians (Finau et al., 2014). The integrity of these posts is mostly unchecked, but the impacts can be real. In 2016, the Pacific's first case of defamation on social media was heard and involved an individual who alleged that the organiser of Fiji's Fashion Week was prostituting young models to white men (Fiji Fashion Week v Emosi Radrodro (High Court of Fiji, January 18, 2017)).

Governments in the Pacific nonetheless are actively seeking to regulate the internet (Finau et al., 2013; Blythe, 2006). The most common justification for the growing moves towards internet censorship is around 'protecting public from destructive thoughts' or 'national security and integrity'. This article examines the two regulatory approaches being developed in the Pacific islands region in response to the emergence of social media; first, through the development of legislation to prosecute cybercriminals and second, through the banning of specific internet sites, most notably the banning of popular social media site Facebook. With regards to banning specific sites, Nauru is the first country in the Pacific region to successfully ban the use of Facebook (Farrell, 2015) while Papua New Guinean government is proposing to block Facebook for a month to research PNG users of Facebook (Roy, 2018).

\section{ICT landscape in the Pacific}

While Information and Communications Technologies (ICTs) and social media platforms are relatively new phenomena to the Pacific region, statistics show that ICT elements such as mobile phone and internet accessibility have been 


\begin{tabular}{|l|l|c|c|c|c|c|c|c|c|}
\hline \multirow{2}{*}{ Table 1: Internet users, social media use for PICs, 2017} \\
\hline & $\begin{array}{c}\text { Popula- } \\
\text { tion }\end{array}$ & \multicolumn{2}{|c|}{ Internet Users } & \multicolumn{2}{c|}{$\begin{array}{c}\text { Active Social } \\
\text { Media Users }\end{array}$} & \multicolumn{2}{c|}{$\begin{array}{c}\text { Mobile } \\
\text { Connections }\end{array}$} & $\begin{array}{c}\text { Active Mobile } \\
\text { Social Media } \\
\text { Users }\end{array}$ \\
\cline { 2 - 13 } & $(000$ 's) & 000's & $\begin{array}{c}\text { \% Popu- } \\
\text { lation }\end{array}$ & 000's & $\begin{array}{c}\text { \% Popu- } \\
\text { lation }\end{array}$ & 000's & $\begin{array}{c}\% \text { Popu- } \\
\text { lation }\end{array}$ & 000's & $\begin{array}{c}\% \text { Popu- } \\
\text { lation }\end{array}$ \\
\hline Cook Islands & 17.4 & 11.38 & 65 & 9.5 & 55 & 9.38 & 54 & 8.6 & 49 \\
\hline Fiji & 908.6 & 500 & 55 & 500 & 55 & 1290.6 & 142 & 470 & 52 \\
\hline Kiribati & 117.4 & 32 & 27 & 32 & 27 & 24.3 & 21 & 30 & 26 \\
\hline $\begin{array}{l}\text { Marshall } \\
\text { Islands }\end{array}$ & 53.15 & 21 & 40 & 21 & 40 & 50.02 & 94 & 20 & 38 \\
\hline Nauru & 11.34 & 6.06 & 54 & 38 & 34 & 10.58 & 93 & 3.4 & 30 \\
\hline $\begin{array}{l}\text { Papua New } \\
\text { Guinea }\end{array}$ & 8330 & 0.91 & 11 & 0.73 & 9 & 361 & 43 & 0.67 & 8 \\
\hline Samoa & 197.1 & 100 & 51 & 100 & 51 & 142.1 & 72 & 94 & 48 \\
\hline $\begin{array}{l}\text { Solomon } \\
\text { Islands }\end{array}$ & 617.3 & 75 & 12 & 75 & 12 & 479.6 & 78 & 68 & 11 \\
\hline Tonga & 108.5 & 57 & 53 & 57 & 53 & 106.9 & 99 & 54 & 50 \\
\hline Tuvalu & 11.24 & 5.17 & 46 & 1.9 & 17 & 8.49 & 76 & 1.7 & 15 \\
\hline Vanuatu & 279.2 & 82.8 & 30 & 69 & 25 & 251.8 & 90 & 63 & 23 \\
\hline
\end{tabular}

Source: We Are Social. Digital in 2018 Report: Internet users, social media use and population statistics for Pacific Island Countries in 2017.

increasing at exponential levels (Titifanue et Tarai, Kant \& Finau, 2016; Titifanue, Kant, Finau \& Tarai, 2017). Pacific Islanders are becoming consumers of ICT technologies. In many Pacific Islands, the use of mobile phone technology has become pervasive, especially in urban centres. At the same time, increasing penetration rates have resulted in their use exponentially increasing in rural areas. Mobile phone penetration in the Pacific has grown to the extent that it has far outstripped fixed line usage (Titifanue et al., 2016; Titifanue et al., 2017).

With the rapid ICT development and innovations taking place around the world, there is enormous potential for exponential increases in the use of social media in the Pacific. Social media thus has significant potential to play a role in developing political discourse and activism within the Pacific region. Writers such as Walsh (2010) have provided analysis on the rise of alternative forms of information dissemination and discussions of political developments due to curtailment of media freedom in Fiji after the 2006 coup. Additionally, other writers have found that in the Pacific, social media enables the discussion and dissemination of information relating to issues censored from traditional media (Finau et al., 2014; Tarai et al., 2015). Through social media, citizens can criticise government policies and to some extent hold government officials to account (Cave, 2012; Logan, 2012). 
Recent scholarly research has demonstrated how citizens and activists have used the democratic potential of the internet to bring about social and democratic change. Finau et al. (2015) have demonstrated how political Facebook groups like Yumi Tok Tok Stret (Vanuatu), Forum Solomon Islands International (FSII Solomon Islands) and the Letters to the Editor Uncensored (Fiji) is facilitating e-democracy, thereby transforming political processes by developing new forms of accountability and transparency. To this end, FSII transformed itself from a Facebook discussion forum to charitable organisation, with a set governance structure and a thriving online site for free and moderated speech. As demonstrated by Tarai et al. (2015), politicians have started actively employing social media for political campaigning in order to directly engage with their voters and constituents in the context of the restrictive media environment in Fiji. In PNG, politicians (mainly Brian Kraemer and Garry Juffa) have also started leveraging Facebook to expose government corruption and calls for greater accountability and transparency.

Robie (2017) and Titifanue et al. (2016) demonstrate how Pacific Islanders have leveraged social media as a means to report on human rights issues in repressive media countries such as West Papua. Titifanue et al. (2017) further demonstrate how local, national and regional groups and organisations in the Pacific concerned with, and striving to address, the issue of climate change are using platforms afforded by the internet for climate change advocacy both nationally and internationally. Both in the context of West Papuan activism and climate change advocacy, ICT tools and platforms have rejuvenated a bottom-up push for regional solidarity and identity. Additionally, young technology-savvy feminists in Fiji have leveraged social media's potential to challenge patriarchal attitudes, calls for more gender-responsive institutions and public policies (Brimacombe, Kant, Finau, Tarai \& Titifanue, 2018).

Digital technologies are also providing a space for Pacific Islanders' voices to be heard in times of natural disasters. Using Tropical Cyclone Pam in Vanuatu, Spyksma (2017) and Tropical Cyclone Winston in Fiji (Finau et al., 2018) argue digital technologies are enabling NGOs and citizens in documenting the impact of the cyclone for its international advocacy; they unintentionally acted to fill a global news gap for reporting from the Pacific region.

\section{Media freedom in the Pacific under siege}

Media and communication networks in the Pacific Islands region are heterogeneous (Papoutsaki \& Harris, 2008; Papoutsaki, McManus, \& Matbob, 2011). Numerous researchers reveal that these diverse forms of media and communication networks play a vital role in the socio-economic and political change in the region (Harris, 2014; Robie, 2014). While the radio remains the most effective and far-reaching coverage in the region and television maintains viewership 
mostly in urban centres, the print media is undergoing significant changes with the advent of ICT revolution, with many newspapers now accessible online (Tacchi et al., 2013). The ICT revolution that the region is undergoing is having an impact on the media and communication landscape, with many people now accessing radio via mobile phones (Cave, 2012; Intermedia Europe, 2012).

Despite the existence of numerous media bodies and associations, the state of media freedom in the Pacific is fragile and tenuous at best (Perrottet \& Robie, 2011). Media in the region have faced a 'growing minefield of media abuses', ranging from unofficial clampdowns on freedom of expression in Tonga to violent attacks on media staff in Vanuatu and PNG, and official laws silencing criticism of Fiji's military-backed government (Robie, 2014). Since 2015, some governments have called for the media to focus on a developmental, nation-building role, rather than playing a watchdog role, denouncing it as overly critical, even destructive (Singh, 2015). Fiji has one of the most draconian legislative frameworks for restrictive media, and other countries (such as Papua New Guinea, Solomon Islands, and Vanuatu) have declared their intention to set up similar legislative frameworks to control media (Pokiton, 2015; Shing, 2015).

The internet and especially social networking sites are having a profound impact on the media in the region. Facebook is being increasingly utilised by activists acting as citizen journalists who are 'playing an active role in the process of collecting, reporting, analysing and disseminating news and information', ranging from commenting on an existing news piece to publishing articles (Singh, 2015). Governments are routinely accused of corruption on Facebook forums. Unhappy about the unprecedented level of public scrutiny and criticism afforded by the internet, governments are becoming increasingly concerned by the unlimited access to information provided by the internet. They are also increasingly concerned by the propagation of provocative and abusive content on social media, and the potentially destabilising impact on their comparatively small and fragile societies, are proposing harsher controls (Singh, 2015).

\section{Government attempts to regulate the internet in the Pacific}

Throughout the region, individual country responses to cybercrime vary significantly, and most changes are quite recent. While Tonga, Nauru and PNG have created new legislation specifically to prosecute individuals for cybercrime offences; Fiji and Samoa has added specific provisions within their existing crimes legislation that addresses forms of cybercrime (Fiji Crimes Act, 2009; Samoa Crimes Act, 2013). Additionally, Fiji in 2018 passed the Online Safety Act aimed at protecting the vulnerable from the excesses of the internet.

Legislation is a means to ensure that people will be prosecuted for committing an offence. However enforcement, especially given the limited resources of the Pacific, and also the difficulties in tracking cybercriminals who hide behind 
aliases and fake accounts, presents a significant challenge for the Pacific. The laws in themselves are not sufficient to bring people to justice or to deter people from committing cybercrime. While Nauru is the only country in the region to place a national ban on Facebook in May 2015, lasting almost three years (RNZ, 2018), governments in Papua New Guinea and Samoa have called for or threatened to ban Facebook. The following sections details with attempts by the Pacific Islands governments to control the internet.

\section{Papua New Guinea: The Cybercrime Code Act (2016) and calls for a temporary Facebook block}

Papua New Guinea's Cybercrime Code Act was passed and certified on the 13 December, 2016 (Government of Papua New Guinea, 2016). The government defines cybercrime as 'offences committed using electronic devices, systems and or networks' (Government of Papua New Guinea, 2014). The Act is predicated on the Papua New Guinea Cybercrime Policy, which was initiated in 2014 (Government of Papua New Guinea, 2014).

PNG's Communication Minister Jimmy Miringtoro had highlighted security concerns for individuals, government agencies and corporate entities as one of the government's main agenda on cybersecurity (Mou, 2016). The minister went further to emphasise the need for updated laws to be responsive to the rising cases of cybercrime and threats to information security in PNG's liberalising ICT market (Mou, 2016). The Act carries a penalty of one million Kina maximum (approximately $\mathrm{A} \$ 400,000$ ) for a whole range of illegal online activities such as - but not limited to - hacking, data and system interference, electronic fraud and forgery, pornography, animal pornography, child pornography and defamatory publication (Government of Papua New Guinea , 2016). The previous legislation did not address cybercrime in its multifaceted aspects but was more direct and limited, such as the Criminal Code Act, 1974, which dealt with pornography specifically. This act was part of 19 other legislations that were deemed relevant to Cybercrime and related offences.

However, the Cybercrime Code Act has been criticised by the opposition, journalists and activists for its implications on freedom of expression, political discourse, lacking consultation and weak justification of threat (RNZ, 2014). The capability of expansive ICT devices as a tool to galvanise public dissent and dissatisfaction was witnessed in what was labelled as the 'PNG Spring' of April 2012 (Logan, 2012). The 'PNG Spring' saw widespread political protests that were addressed by PNG bloggers, which indicated how vibrancy PNG's blogosphere (Logan, 2012) was. Therefore, the introduction of the Cybercrime Policy a little less than two years later in 2014 received strong suspicion and criticism from the PNG opposition leader at the time, Belden Namah, who stated that 'the new policy will block freedom of speech' (RNZ, 2014). Namorong and 
a variety of other critics were particularly concerned about the lacking clarity in the references to 'defamation' made in the Act (Galgal, 2017; Namorong, 2016). The section on Defamatory Publication highlights electronic material that can be deemed to directly or indirectly harm a person's reputation, profession and also if such material causes other people to 'avoid' the supposed defamed person (Government of Papua New Guinea, 2016). The blurred line between this section and internet censorship becomes evident when the Act does not have a clear section or subsection which protects freedom of expression, specifically critical political discourse. Critical political discourse in highlighting accountability issues, especially from public office holders runs the risk of being dismissed as 'defamatory material'. Therefore, a citizen seeking accountability online can be easily exploited by a disgruntled public official and be imprisoned or fined.

The Act has also been criticised for lacking critical and transparent consultations, especially in excluding the media industry, as expressed by the former PNG Media Council president, Alexander Rheeney (Pacific Media Watch, 2017). This argument is coupled by the fact that the Cyber Crime Policy, which later informed the Cybercrime Code Act, enlisted only 314 respondents to a vague survey, in a country of more than 7 million people, with less than one million active social networking site users (Government of Papua New Guinea, 2016). The policy has also been criticised for poorly concealing the fact that it failed to determine and contextualise the level of threat that cybercrime posed in Papua New Guinea. In a section titled 'Challenges in Determining the Threat Level', the policy has emphasised global data on cybercrime as a point of concern but veiled the fact that it was not able to produce contextual cybercrime data relevant to PNG (Government of Papua New Guinea, 2014). This exposed the tenuous justification of cybercrime as a threat in Papua New Guinea and ultimately the genuinity and purpose of the Act itself, as claimed by the government.

In addition to the Act, on 29 May, 2018, the PNG Post-Courier reported an announcement by the government of PNG that it was contemplating imposing a 'temporary' block on Facebook to investigate how best to regulate the site (Geteng, 2018). The PNG Communications Minister Sam Basil further stated that PNG could also look at the potential for creating a new Social Networking Site specifically for Papua New Guineans within PNG and abroad (British Broadcasting Corporation, 2018).

The motivation for the proposed blocking of Facebook was in response to illegal uses of Facebook in order to enforce PNG's Cybercrime Act 2016. The minister stated that 'the time will allow information to be collected to identify users that hide behind fake accounts, users that upload pornographic images, users that post false and misleading information on Facebook to be filtered and removed' (Geteng, 2018; Tlozek, 2018). While the minister later denied that his ministry planned to ban Facebook, the Post-Courier, which initially broke 
the news on the proposed ban stood by their story (PNG Post-Courier, 2018).

Overall the PNG government rhetoric has been that they want 'genuine people with real identities to use the social network responsibly' (RNZ, 2018b). However, the motives for the move came under significant criticism from parties both within and outside PNG. Criticisms were raised that with a growing mistrust of local media in PNG (Gware, 2018), many Papua New Guineans were being pushed towards social media and that shutdowns, whether fully or partially, are typically undertaken by regimes attempting to suppress freedom of expression (Galgal, 2018). In a similar parallel to Nauru (discussed later), critics have also highlighted that the proposed ban seems to be censorship being disguised as protection (Galgal, 2018). PNG opposition MP Bryan Kramer also questioned the logic of a research methodology that would shut down the platform in order to research it (Kramer, 2018). It is worth noting that after Kramer raised this opinion in a Facebook post titled "DID DUMB JUST GET DUMBER???", he was referred to the Parliamentary Privileges Committee (Patjole, 2018b). The opposition strongly criticised this move as being a 'ploy to censor freedom of expression' (Patjole, 2018a).

At present, PNG has low internet penetration levels with about 11 percent of Papua New Guineans having Internet access, and approximately 730,000 active Facebook users (We Are Social, 2018). However, it must be noted that despite this limited internet outreach, PNG citizens are harnessing the internet and the information flows that it provides. Government attempts at internet censoring are not a new phenomenon: in 2010, the PNG government made its first attempt, when citizens leaked copies of a corruption enquiry report on blog sites (Logan, 2012). The government reacted by sending a writ to the country's ISP and ordered them to block blogs, which hosted the report (Logan, 2012).

Besides, PNG has an uninspiring score concerning press freedom, with a ranking of 53 in the 2018 World Press Freedom Index. Reporters Without Borders (2018) describes press freedom in Papua New Guinean as 'real but fragile freedom'. In such an environment, social media plays a crucial role in keeping the public informed on matters that the mainstream media may have missed (Hopkinson \& Driscoll, 2017). Opposition politicians have also harnessed the internet as a means to disseminate information to the public and critique government policies. It is also noteworthy that PNG's current Communications Minister has ardently spoken out against Facebook had been previously described in 2011 as an MP who 'uses Facebook extensively to communicate with the public' (Stewart, Dwyer, \& Lagerstedt, 2011).

\section{Fiji: The Online Safety Act, 2018}

The Parliament of Fiji enacted the Online Safety Act in May 2018 (Fijian Government, 2018), has been promoted as legislation designed to protect 
Fijians against online forms of abuse and harm (Swami, 2018). These include cases of cyberbullying, harassment and manipulation through threats of exposure of intimate images, videos and or any other online material (FBC News, 2018). There has been an increase in the reporting of cyberbullying, harassment and manipulation in recent years within Fiji's media landscape. This has created a veneer of necessity and justification for the Act. However, critics remain suspicious of the Act and the intent of the Fijian government (Prasad, 2018).

Opposition concerns around the Bill mostly have to do with the implications on free speech and critical discussions (Swami, 2018). Robie \& Perrottet (2011), point out that Fiji's media has been fragile due to its censorship in the early days of the 2006 coup. This has impacted on the free flow of information and also the expansion of online activity and discussions. Online debates and discussions have become crucial in informing and updating Fijians. Therefore, it is difficult for critics to fully trust or accept the purported intent of the Online Safety Bill, especially when its media landscape has been a victim of censorship from the same administration. At the time of writing, the Online Safety Act was only a few months old, and their implications on online discussions are yet to be seen.

\section{Tonga: The Cyber Crime Legislative Framework (2011)}

Tonga had introduced its Cybercrime Legislative Framework in 2011, encompassing some laws, which seek to address cybercrime related offences (Kefu, 2011). The primary legislation within this framework is the Computer Crimes Act 2003, which has two main objectives, namely to address computer-related crime and provide for the collection and use of electronic evidence (Kefu, 2011). Other laws in the framework include the Criminal Offences Act, Pornography Control Act; Communications Act 2000; Mutual Assistance in Criminal Matters Act; and Extradition Act (Kefu, 2011). By 2016, there was draft legislation designed to add on to the Crimes Act 2003, which was put forward to parliament (Radio New Zealand, 2016).

In 2016, the Tongan chief executive of the Ministry of Information and Communications has publically stated how difficult it was to 'stop, censor or regulate information on social media' (Radio New Zealand, 2016). In 2017, Tonga signed onto the Budapest Convention on Cybercrime Treaty and signed up with Australia to share cybersecurity information (Matangi Tonga, 2017). The legislative framework appears to be broad, and its implications on online free speech are yet to be seen.

\section{Proposed cybercrime legislation: Vanuatu, Samoa and the Solomon Islands}

Governments in Vanuatu, Samoa and Solomon Islands have all indicated that they are in the process of drafting legislation on cybercrime. While Vanuatu and Samoa have been working with the Australian Government and the Council of Europe in preparing the bill. Much like other cybercrime, bills in the Pacific, 
it is drafted with the intent to protect their citizens against cybercrime-related activities (Fikiasi, 2013; RNZ, 2018; Ah-Hi, 2018).

The Ni-Vanuatu government, which has been critical of discussions on both traditional and social media, warned of introducing a law to curb 'excessive liberty', including unwarranted allegations and abusive comments made on radio talkback shows and social media (Shing, 2015). The then Kilman government singled out the Yumi Toktok Stret Facebook group, and accused it of 'inciting social anarchy, instability and social disorder'. The wrong use of media could 'easily destabilise' the social peace and order in a vulnerable country like Vanuatu, said Kilman (Shing, 2015). Statements by the then PM were criticised that while some concerns about some of the excesses were reasonable, the government's reaction was disproportionately strong (International Federation of Journalists 2015). While the Cybercrime legislation while still in the drafting process, the current Prime Minister Charlot Salwai admitted that part of the bill was targeted at what he termed as 'false claims' on social networking sites such as Facebook and that 'Facebook has gone beyond [control]' (Pacific Media Centre, 2018). He stated that the proposed bill will tabled in Parliament 'so we can control the use of social media' (Pacific Media Centre, 2018).

In Samoa, the Prime Minister, Tuilaepa Sailele Malielegoai, had openly stated his concerns about what he described as the 'illegal skimming of cash flow machines' and the need for Samoa to be up to date with the international community on combating cybercrime (Ah-Hi, 2018). At the time of writing, Samoa has yet to establish specific legislation on cybercrimes and online activity. However, it has introduced amended specific laws, such as the Crimes Act 2013 (2013, No. $10)$ to include crimes concerning online activity. These include sexual offences involving the use of mobile devices and the internet (RNZ, 2013; Samoa Planet, 2018). However, new questions emerge around what cybercrime legislation in Samoa would cover, considering the government's response to 'Ghostwriters' (Finau \& Garae, 2018). In November 2017, the Samoan government had revived a criminal libel law that it had removed in 2013, to address the issue of 'Ghostwriters' (Samoan Observer, 2017). Online social media users with pseudonyms have been disdainfully dubbed 'Ghost Writers', for their writings mostly targeted towards the Samoan government (Samoa Planet, 2017; Samoan Observer, 2017).

In an effort to bring the 'Ghostwriters' to task, the government in late 2017 re-introduced the Criminal Libel Law, which was abolished in 2013 (Luamanu, 2017). In addition to this, the Samoan Prime Minister threatened to ban social media platforms from Samoa completely if 'gutless anonymous bloggers' continue to use the freedom social media affords them to abuse government officials and innocent members of the public (Luamanu, 2018). The government is working on strengthening this legislation that already exist to meet, regulate and prosecute cybercriminals (Finau \& Garae, 2018). 
While there are no plans in motion by the government to draft cybercrime legislation in the Solomon Islands, the Director of Public Prosecution, Ronald Bei Talasasa, indicated a need for cybercrime legislation to overcome the vulnerability of the country to cybercrimes and other related activities (Bilua, 2017). The director had also mentioned Facebook specifically being a site where '...people are just running free...' and that 'it is time for people to think again' (Bilua, 2017). In recent years former Prime Minister Manasseh Sogavare has threated to have the Facebook group, Forum Solomon Islands International (FSII), deregistered because of what he had then claimed was the group's 'political nature' (Aatai, 2015). FSII over the years has built significant citizen awareness and drive towards greater accountability, transparency and responsibility from government officials and their planned policies, registering as a non-government organisation with a set governance structure and a thriving online site for free and moderated speech (Finau et al., 2014; Afuga, 2014; Afuga, 2015).

\section{The Nauru Facebook ban}

On 1 May, 2015, the government of Nauru announced through a media release that access to a site showing pornography (particularly children) would be blocked. Also, the government revealed in 2015 that new cybercrime laws were being drafted (The Government of the Republic of Nauru, 2015a). In undertaking the crackdown on pornographic sites, the Nauru government directed the island's sole internet service provider (ISP) Digicel, to block specific sites. As a result, numerous 'applicable' sites were blocked (Raines, 2015). The Nauru government justified its use of the method of blocking of various sites because Nauru possesses limited resources and cannot thus monitor the internet (The Government of the Republic of Nauru, 2015a).

In justifying the ban, the Nauruan Minister of Justice, David Adeang, alluded to an increase in children exposed to explicit content. He added that 'Nauru is a small country with limited resources, and we cannot monitor the internet like larger nations, so this move and our new laws are both significant measures" (Government of the Republic of Nauru, 2015a). In a further press release on the 13 May, the President of Nauru argued that the internet blocks enacted would serve to protect women and children better, stating that such blocks were '.. part of the government's efforts to curb the glorification of criminal activities and offences against Nauruan women and children through the posting of distressing images and footage of these individuals in compromising and dehumanising positions' (Government of the Republic of Nauru, 2015b).

While the Nauruan government has cited moral grounds, and the aim to protect children from pornography, as critical reasons for the blocks enacted, it has come under fire from numerous parties including CSOs, NGOs, opposition MPs, and refugee advocates (Radio Australia, 2015a). Those in opposition to 
the Nauruan government actions have argued that the rhetoric of morality and child protection have been a veil for the censorship of social media and stifling of criticisms directed at the government (Farrell, 2014). In an interview with Pacific Beat, opposition MP Matthew Batsiua dismissed the government's claims of being motivated by 'moral grounds', and stated the first reason they gave [for the closure] was due to a technical problem. Now it is all about porn' (Radio Australia, 2015a).

The Nauruan government also came under fire by refugee support groups who viewed its move as a means to stifle the voice of refugees, detained indefinitely in Nauru, seeking entry into Australia. The Nauru government initially denied that social media sites had been subjected to the 'blocks'. In a government media release almost a month after the implementation of the 'crackdown on pornography', the Nauru Minister of Justice stated that 'The internet in Nauru is completely open except for those pornographic sites', and that 'those who are living as refugees in Nauru have complete access to all communications including phone, internet, email and a myriad of social media platforms' (Government of the Republic of Nauru, 2015c). However, Facebook administration confirmed that their data revealed that their site had indeed been blocked in Nauru (RNZ, 2015a). In response to the statement by Facebook, the Nauruan government denied a deliberate move to block Facebook but did concede that some social media sites may have been blocked temporarily (RNZ, 2015a).

Nauru's moves to ban 'applicable sites' to curb child pornography may appear to be a move in the right direction, but when taken in the broader political context of Nauru, the social media ban reveals arguably ulterior motives. In 2013, a trend of censorship began, with the Nauruan government preventing local television from airing concerns by opposition politicians on an asylum seeker deal with Australia, with the Nauruan Minister of Justice alluding to the fact that this ban was needed in order to prevent confusion about the agreement (Flitton, 2013). Further to this, in January 2014, Nauru increased the visa application fee for foreign journalists by 4,000 percent, with a single-entry media visa now costing A $\$ 8,000$ which is non-refundable should the visa application be rejected (Government of the Republic of Nauru, 2018). This move has come under significant fire as being a means to limit media coverage of activities taking place within the refugee detention centre on Nauru. The refugee detention centre has repeatedly come under fire, for the mistreatment of refugees in the centre, with UN organisations, the Australian Human Rights Commission and Amnesty International has highlighted refugees being victims of neglect, assault, and denial of essential services (Amnesty International, 2016; Australian Human Rights Commission, 2016). A culture of secrecy has been imposed on Nauru, with many journalists (particularly from Australia) and researchers being refused permission to visit (Human Rights Watch, 2016). RNZ (2018a) 
reported in January this year that only two Australian journalists have visited Nauru since the inception of the increased visa fees.

When the context above is taken into account Nauru's motivations in banning Facebook denote sinister implications, particularly so given the vociferous denials on the part of the Nauruan Minister for Justice that social media sites had not been banned despite reports from Facebook to the contrary (Radio New Zealand, 2015a; Government of the Republic of Nauru, 2015c). It is further worth noting that the denials by the Nauruan government of Facebook being blocked were reported by RNZ (2015b) on May 1. However, by May 29, Nauru's president was vigorously defending a Facebook ban, by alluding to Facebook's power to 'disrupt, embarrass, destroy one's reputation and to create instability' (Radio Australia, 2015b). Furthermore, allegations have been made that the banning of Facebook in Nauru came about at the instigation of the Australian government (Raines, 2015).

Overall, the government of Nauru has claimed noble intentions in its banning of social media. However, an analysis of political trends within Nauru reveals a political culture of political dissent being stifled, and high visa fees hindering impartial media from entering the country - this is repetitive. In such a repressive media environment, social media plays a crucial role in disseminating information through citizen media and fostering activism (Robie, 2017; Titifanue et al., 2017; Titifanue et al., 2016). Blocking of Facebook when placed in Nauru's broader political context reveals a transparent attempt by the government to stifle dissent from opposition politicians and citizens, as well as limit the dissemination of information on the treatment of asylum seekers.

\section{Conclusion}

As the internet grows by leaps and bounds, its social and political applications and their implications have risen respectively. The global diffusion of the internet has created a growing challenge for many democratic and authoritarian regimes and significantly enabled the growth and effectiveness of global civil society. This trend is also visible in the Pacific. Online petitions and protests, calls for action, advocacy of various marginalised political causes, and the rise of the blogosphere have become an integral part of the political and social action, allowing local, regional and global social movements to reach national and global audiences. In response, government censorship, ranging from relatively mild steps such as anti-pornography measures to lose control of internet content has become an inevitable element of the characteristics of cyberspace.

The struggle for creating viable and vibrant democratic societies in the Pacific Islands continues to be an ongoing battle. This article has painted a troubling picture of online freedom of expression in the Pacific. Despite the relatively low levels of internet penetration, and internet accessibility being a comparatively 
urban phenomenon, governments in the region are determined to regulate the internet. So far two approaches have been used to control freedom of information and communication: regulation via legislation, and outright banning of Facebook under the pretext of protecting its citizens from harmful excesses of the internet. While the move by Pacific governments might seem reasonable, there are reasons to remain sceptical. Pressure on new media through regulation in the Pacific should be contextualised in the broader issue of media freedom. While the state of media freedom remains precarious, these new moves to regulate the Internet, coupled with lack of public consultations, signals a worrying trend for freedom of expression and rights to information in the Pacific Islands region.

While there are strong reasons to keep the internet free from unnecessary regulation, it is however acknowledged that some regulation must occur to protect the rights of all Internet users. Regulation of the internet should be considered in the frame of new policies, which are designed to protect illegal and harmful internet content whereas deliberations and decisions need to be transparent and democratic. Respect for freedom of speech and privacy of communication should also be taken into consideration. When this regulation does occur, the government should not dominate it but rather involve the engagement of all stakeholders including the wider public. Freedom of information and communication protections must continuously be re-analysed in light of new technology that continuously increases people's ability to communicate. In order to guarantee that citizens have a voice in the privately run internet spaces where they spend increasing amounts of time, the law must embrace new approaches to protecting digital rights: namely by carving out rights of access, speech, and transparency and accountability in online spaces.

\section{Notes}

1. www.facebook.com/bryan.kramer.90. MP Byran Krammer also has a Facebook page, The Krammer Report, an independent blog providing articles and commentary on political and socio-economic issues affecting Papua New Guinea by revealing systemic injustice and endemic corruption through in-depth investigative reporting and critical analysis. The page can be accessed at www.facebook.com/kramerreportpng/

2. www.facebook.com/garyjuffa/

3. Seepg. $6 \& 7$ forthe19ActsrelevanttoCybercrime(PNGCybercrimePolicyBackground). www.unodc.org/res/cld/lessons-learned/png/papua_new_guinea_cybercrime_policy_ html/PNG_Cybercrime_Policy.pdf

\section{References}

Aatai, J. (2015, October 19). PM wants FSII deregistered. Solomon Star. Retrieved from http://www.solomonstarnews.com/index.php/news/national/item/16412-pmwants-fsii-deregistered 
Afuga, B. (2014, May 1). FSII-History, structure and plans for the future. (J. Tarai, Interviewer).

Afuga, B. (2015, November 27). Deregistering FSII — what do you think as an administrator? Online Communication. (Jope, Interviewer).

Ah-Hi, E. (2018, July 3). Samoa combats cyber-crime. Samoa Observer. Retrieved from http://www.samoaobserver.ws/en/03_07_2018/local/34660/Samoa-combatscyber-crime.htm

Amnesty International. (2016). Island of despair: Australia's 'processing' of refugees on Nauru. London, UK: Amnesty International.

Australian Human Rights Commission. (2016, February 4). New report: Experts reveal alarming impact of detention on children. Australian Human Rights Commission. Retrieved from www.humanrights.gov.au/news/stories/new-report-experts-revealalarming-impact-detention-children

Bilua, B. (2017, September 20). Solomon Islands vulnerable to cybercrime. Islands Sun. Retrieved from http://theislandsun.com.sb/solomon-islands-vulnerable-cyber-crime/

Blythe, S. E. (2006). South Pacific computer law: Promoting E-commerce in Vanuatu and fighting cyber-crime in Tonga. Journal of South Pacific Law, 10(1), 2009.

Brimacombe, T., Kant, R., Finau, G., Tarai, J., \& Titifanue, J. (2018). A new frontier in activism: An exploration of digital feminism in Fiji. Asia Pacific Policy Studies, 5(3), 508-521.

British Broadcasting Corporation. (2018, 29 May). Facebook to be banned in Papua New Guinea for a month. Technology. Retrieved from www.bbc.com/news/technology-44290012

Council of Europe. (2001). Convention on Cybercrime. Retrieved from www.coe.int/ en/web/conventions/full-list/-/conventions/treaty/185

Farrell, P. (2014, May 4). Facebook blocked on Nauru due to 'paranoia' about media scrutiny, says former president. The Guardian. Retrieved from www.theguardian. com/world/2015/may/04/facebook-blocked-on-nauru-due-to-paranoia-about-mediascrutiny-says-former-president

Farrell, P. (2015, May 11). Nauru says Facebook block a 'temporary restriction' to keep public safe from 'sexual perverts'. The Guardian, p. 11.

Fiji Fashion Week v Emosi Radrodro. (High Court of Fiji, January 18, 2017). Pacific Islands Legal Information Institute.

Fikiasi, L. M. (2013, December 3). Cybersecurity: Policy development and challenges for Vanuatu. Retrieved from www.trr.vu/attachments/article/111/cybersecurity_forum_presentation_in_malaysia_2013.pdf

Finau, G., and Garae , J. 2018. Is Samoa's cybercrime regulation protecting its people or quashing dissent? East Asia Forum. Retrieved from http://www.eastasiaforum. org/2018/08/25/

Finau, G., Prasad, A., Kant, R., Tarai, J., Logan, S., \& Cox, J. (2014). Social media and e-democracy in Fiji, Solomon Islands and Vanuatu. In 20th Americas Conference on Information Systems. AIS (Association for Information Systems).

Finau, G., Cox, J., Tarai, J., Kant, R., Varea, R., Titifanue, J. (2018). Social media and disaster communication: A case study of Cyclone Winston. Pacific Journalism Review, 24(1), 123-137.

Finau, G., Samunawai, J., \& Prasad, A. (2013). Cybercrime and its implications to the Pacific. Retrieved from QUT ePrints: https://eprints.qut.edu.au/69108/

Finau, G., Samuwai, J., \& Prasad, A. (2013). Cybercrime and its implications to the Pacific. The Fiji Accountant, 15-16. 
Finau, G., Tarai, J., Acklesh, P., Logan, S., Cox, J., \& Kant, R. (2014). Social media and e-democracy in Fiji, Solomon Islands and Vanuatu. Retrieved from repository.usp. ac.fj/7796/1/Social_Media_and_eDemocracy.pdf

Flitton, D. (2013, August 6). Nauru TV censored over asylum seeker deal. The Sydney Morning Herald. Retrieved from https://www.smh.com.au/politics/federal/nauru-tvcensored-over-asylum-seeker-deal-20130806-2rck3.html

Galgal, K. (2017, March 16). Developing PNG's cybercrime policy: Local contexts, global best practice. The Interpreter. Retrieved from https://www.lowyinstitute. org/the-interpreter/developing-png-s-cybercrime-policy-local-contexts-global-bestpractice

Galgal, K. (2018, 5 June). What a partial internet shutdown would mean for PNG. The Interpreter. Retrieved from https://www.lowyinstitute.org/the-interpreter/whatpartial-internet-shutdown-would-mean-png

Geteng, B. (2018, 29 May). Shutting down Facebook in PNG is a reality. PNG PostCourier. Retrieved from https://postcourier.com.pg/shutting-facebook-png-reality/

Government of Papua New Guinea. (2016, December 13). Cybercrime Code Act 2016. No.35 of 2016 -Cybercrime Code Act 2016. Port Moresby.

Government of Papua New Guinea. (2014). Papua New Guinea Cybercrime Policy. Retrieved from United Nations Office on Drugs and Crime www.unodc.org/res/ cld/lessons-learned/png/papua_new_guinea_cybercrime_policy_html/PNG_Cybercrime_Policy.pdf

Gware, C. (2018, 2 June). Issue of 'paid' journos to be raised in Parlt. Loop PNG. Retrieved from http://www.looppng.com/png-news/issue- $\%$ E2\%80\%98paid\%E2\%80\%99journos-be-raised-parlt-77042

Hopkinson, J., \& Driscoll, H. (2017, 14 June). How traditional and social media will impact on PNG elections. Asia Pacific Report. Retrieved from https://asiapacificreport.nz/2017/06/14/how-traditional-and-social-media-will-impact-on-png-elections/

Human Rights Watch. (2016, 2 August). Australia: Appalling abuse, neglect of refugees on Nauru. Retrieved from https://www.hrw.org/news/2016/08/02/australia-appallingabuse-neglect-refugees-nauru

International Federation of Journalists. (2015). Strengthening media in the Pacific: Country Situational Reports from Papua New Guinea, Solomon Islands and Vanuatu.

Joshua, J. (2017, 05 21). Vanuatu chief information officer to begin consultations on Cybercrime Bill. Pacific Islands Report. Retrieved from www.pireport.org/articles/2017/05/21/vanuatu-chief-information-officer-begin-consultations-cybercrime-bill

Kefu, A. (2011, November 21-23). Tonga's cybercrime legislation.

Kramer, B. (2018). Personal Facebook post. Facebook. Retrieved from https://www. facebook.com/bryan.kramer.90/posts/1994897817429600

Kshetri, N. (2013). Cybercrime and cybersecurity in the developing Pacific Island economies. In Cybercrime and cybersecurity in the global south (pp. 171-189). London: Palgrave Macmillan.

Logan, S. (2012). Rausim!: Digital politics in Papua New Guinea. SSGM Discussion Paper, The Australian National University, 2012(9).

Luamanu, J. (2017, December 19). Parliament brings back criminal libel. Samoa Observer. Retrieved from http://www.samoaobserver.ws/en/20_12_2017/local/28040/Parliamentbrings-back-Criminal-Libel.htm

Luamanu, J. (2018, September 24). PM threatens to ban Facebook. Samoa Observer. Retrieved from http://www.samoaobserver.ws/en/01_04_2018/local/31711/PMthreatens-to-ban-Facebook.htm 
Matangi Tonga. (2017). Tonga cybercrime update. Matangi Tonga Online. Retrieved from https://matangitonga.to/tag/cybercrime?page $=1$

May, R. (2017). Papua New Guinea under the O'Neill government-Has there been a shift in political style?. Retrieved from ANU - SSGM: http://ssgm.bellschool.anu.edu. au/sites/default/files/publications/attachments/2017-08/dp_2017_6_may.pdf

McGarry, D. (2016, November 26). Cybercrime bill 'unsafe. Vanuatu Daily Post. Retrieved from http://dailypost.vu/news/cybercrime-bill-unsafe/article_20246b0c7b6f-5bba-b766-41dd3de32b80.html

Moore, R. (2014). Cybercrime: Investigating high-technology computer crime. London, UK: Routledge.

Mou, F. (2016, August 11). Parliament passed Cybercrime Code Bill. Loop PNG. Retrieved from http://www.looppng.com/content/parliament-passed-cybercrime-code-bill

Namorong, M. (2016, August 16). Concerns that PNG's cybercrime laws could be used to censor critics. (C. Graue, Interviewer)

Nisha, S., \& Farik, M. (2015). Recent cybercrimes in Fiji. International Journal of Scientific \& Technology Research, 4(8), 148-151.

Pacific Media Centre. (2018, June 26). Vanuatu plans cybercrime law to target Facebook 'false claims'. Asia Pacific Report. Retrieved from https://asiapacificreport. nz/2018/06/26/vanuatu-plans-cyber-crime-law-to-target-facebook-false-claims/

Pacific Media Watch. (2017, June 30). PNG Media Council seeks opinion over Cybercrime Act's 'free speech' impact. Asia Pacific Report. Retrieved from https:// asiapacificreport.nz/2017/06/30/png-media-council-seeks-opinion-over-cybercrimeacts-free-speech-impact/

Parliament of Samoa. (2013). Crimes Act 2013 (2013, No. 10). Samoa.

Patjole, C. (2018a, June 2). Kramer's referral censors freedom of speech: Opposition. Loop $P N G$. Retrieved from http://www.looppng.com/png-news/kramer\%E2\%80\%99sreferral-censors-freedom-speech-opposition-77028

Patjole, C. (2018b, June 1). Opposition Storm out after Kramer's referral. Loop PNG. Retrieved from http:/www.looppng.com/png-news/opposition-storm-out-afterkramers-referral-77015

Perrottet, A., \& Robie, D. (2011). Pacific media freedom 2011: A status report. Pacific Journalism Review, 17(2), 148-186.

PNG Post-Courier. (2018, 31 May). Post-Courier maintains minister did say one month Facebook ban. Retrieved from https://postcourier.com.pg/post-courier-maintainsminister-say-one-month-facebook-ban/

Pokiton, S. (2015, December 9). Govt setting up media tribunal. PNG Loop.

Prasad, B. (2018, May 18). Fiji Online Safety Bill prompts free speech concerns [Audio]. (B. Hill, Interviewer) ABC-Pacific Beat.

Radio Australia. (2015a, May 2). Nauru's ban on Facebook angers opposition and refugee advocates. Retrieved from www.abc.net.au/news/2015-05-02/nauru-ban-on-facebookto-diffuse-dissent-critics-say/6439146

Radio Australia. (2015b, 29 May). Nauru's president defends Facebook ban, says social media has 'power to create instability'. Pacific Beat. Retrieved from http://www.abc. net.au/news/2015-05-29/nauru-president-baron-waqa-defends-facebook-ban/6507240

Radio Australia. (2017). Social media crackdown worries Samoan journalists. Retrieved from http://www.abc.net.au/radio-australia/programs/pacificbeat/social-mediacrackdown-worries-samoan-journalists/9177148

RNZ. (2013, April 29). Voyeurism among offences covered in Samoa's new Crimes Act. Retrieved from https://www.radionz.co.nz/international/pacific-news/211812/ 
voyeurism-among-offences-covered-in-samoa's-new-crimes-act

RNZ. (2014, April 14). Proposed PNG cybercrime law an attempt to shut down criticism:

Namah. Retrieved from http://www.radionz.co.nz/international/pacific-news/241559/ undp-to-pay-ha\%27apai-cyclone-victims-to-clean-debris

RNZ. (2015a, May 4). Facebook confirms Nauru site block. Retrieved from https://www. radionz.co.nz/international/pacific-news/272776/facebook-confirms-nauru-site-block

RNZ. (2015b, May 1). Nauru government denies Facebook shut down Retrieved from https://www.radionz.co.nz/international/pacific-news/272539/nauru-governmentdenies-facebook-shut-down

RNZ. (2016, October 3). Tonga looks at laws to curb cybercrime. Retrieved from https://www. radionz.co.nz/international/pacific-news/314739/tonga-looks-at-laws-to-curb-cyber-crime

RNZ. (2016). Tonga looks at laws to curb cybercrime. Retrieved from https://www.radionz.co.nz/international/pacific-news/314739/tonga-looks-at-laws-to-curb-cyber-crime

RNZ. (2018, July 2). Samoa gets help from EU and Australia to fight cybercrime. Retrieved from https://www.radionz.co.nz/international/pacific-news/360893/samoagets-help-from-eu-and-australia-to-fight-cybercrime

RNZ. (2018). Nauru lifts Facebook ban. Retrieved from https://www.radionz.co.nz/ international/pacific-news/349319/nauru-lifts-facebook-ban

RNZ. (2018a). Nauru to waive media visa application fee for Forum. Retrieved from https://www.radionz.co.nz/international/pacific-news/348824/nauru-to-waive-mediavisa-application-fee-for-forum

Raines, S. (2015, May 5). Australia allegedly requested Nauru Facebook ban. Radio Australia. Retrieved from http://www.pireport.org/articles/2015/05/05/australiaallegedly-requested-nauru-facebook-ban

Reporters Without Borders. (2018). Papua New Guinea. 2018 World Press Freedom Index. Retrieved from https://rsf.org/en/papua-new-guinea

Republic Of Vanuatu. (2015). Bill for the Cybercrime Act 2015. Vanuatu.

Robie, D. (2014). Pacific Media Watch and protest in Oceania: An investigative free media case study. Pacific Journalism Review, 20(1), 35-60. https://doi.org/10.24135/ pjr.v20i1.186

Robie, D. (2017). Tanah Papua. Asia-Pacific news blind spots and citizen media: From the 'Act of Free Choice' betrayal to a social media revolution. Pacific Journalism Review : Te Koakoa, 23(2), 159-178. https://doi.org/10.24135/pjr.v23i2.334

Robie, D., \& Perrottet, A. (2011). Pacific Media Freedom 2011: A status report. Pacific Journalism Review : Te Koakoa, 17(2), 148-186. https://doi.org/10.24135/pjr.v17i2.356

Roy, E. A. (2018). Papua New Guinea bans Facebook for a month to root out 'fake users'. The Guardian. Retrieved from www.theguardian.com/world/2018/may/29/ papua-new-guinea-facebook-ban-study-fake-users

Samoa Planet. (2017, November 2). Ghost writers to be prosecuted. Retrieved from Samoa Planet: http://www.samoaplanet.com/ghost-writers-brought-justice/

Samoa Planet. (2018, July 4). Another cybercrime conference? Talk and no action? Retrieved from http:/www.samoaplanet.com/samoa-another-cyber-crime-conferenceall-talk-talk-and-no-action/

Samoan Observer. (2017, November 02). Govt. brings back criminal libel law in hunt for 'ghostwriters'. Retrieved from http://www.samoaobserver.ws/en/03_11 2017/ local/26186/Govt-brings-back-Criminal-Libel-law-in-hunt-for- $\%$ E2\%80\% $\% 8 \overline{\text { Ghost- }}$ writers $\%$ E2\%80\%99.htm

Shing, G. (2015, July 4). VANUATU: Kilman plans media law to curb 'excessive liberty'. Pacific Media Watch. 
Singh, S. (2015). State of the media review in four Melanesian countries_-Fiji, Papua New Guinea, Solomon Islands and Vanuatu — in 2015. SSGM DISCUSSION PAPER, pp. 1-20.

Spyksma, H. (2017). Unintentional journalists: The role of advocacy group 350 in filling a news gap for reporting from the Pacific region. Journalism Studies, 1-21.

Stewart, L., Dwyer, M., \& Lagerstedt, S. (2011, August 4). Social media-driven political activism in Papua New Guinea. Press Release: Bond University Journalism Students. Retrieved from www.scoop.co.nz/stories/WO1108/S00153/social-media-drivenpolitical-activism-in-papua-new-guinea.htm

Swami, N. (2018, May 16). Online Safety Bill. Retrieved from Fiji Times Online: http:// www.fijitimes.com/online-safety-bill/

Tarai, J. (2015). To regulate or not: Fiji's social media. SSGM In-Brief, Canberra.

The Fijian Government. (2018, May 17). Online Safety Bill 2018 - Bill No.7. ONLINE SAFETY BILL 2018 - (BILL NO. 7 OF 2018). Suva, Fiji: Fiji Parliament Secretariat.

The Government of the Republic of Nauru. (2015a). Nauru cracks down on internet Pornography [Press release]

The Government of the Republic of Nauru. (2015b). Nauru president says govt will protect women and children through internet blocks [Press release]

The Government of the Republic of Nauru. (2015c). We have not blocked the internet Nauru government [Press release]

The Government of the Republic of Nauru. (2018). Visa requirements. Retrieved from www.naurugov.nr/about-nauru/visiting-nauru/visa-requirements.aspx

Titifanue, J., Kant, R., Finau, G., \& Tarai, J. (2017). Climate change advocacy in the Pacific: The role of information and communication technologies. Pacific Journalism Review : Te Koakoa, 23(1), 133-149. https://doi.org/10.24135/pjr.v23i1.105

Titifanue, J., Tarai, J., Kant, R., \& Finau, G. (2016). From social networking to activism: The role of social media in the Free West Papua Campaign. Pacific Studies, 39(3), 255-281.

Warf, B. (2011). Geographies of global internet censorship. GeoJournal, 76(1), 1-23.

We Are Social. (2018). Digital in 2018 in Oceania.

Willie, R. (2018, July 17). Vanuatu participates in Octopus conference on cybercrime in France. Vanuatu Daily Post. Retrieved from http://dailypost.vu/news/vanuatuparticipates-in-octopus-conference-on-cybercrime-in-france/article_ab95c39c5588-52bf-8797-ec4fe41c6d4b.html

Romitesh Kant is an honorary research associate at the Institute of Human Security and Social Change (IHSSC), La Trobe University, Melbourne, Australia.

r.kant@latrobe.edu.au

Jason Titifanue is a teaching assistant at the School of Government, Development and International Affairs, The University of the South Pacific, Suva, Fiji; and an honorary research associate at the Institute of Human Security and Social Change (IHSSC), La Trobe University, Melbourne, Australia.

Jope Tarai is a doctoral candidate at the University of New South Wales; and an honorary research associate at the Institute of Human Security and Social Change (IHSSC), La Trobe University, Melbourne, Australia. 
Glenn Finau is a doctoral candidate at the University of New South Wales; an assistant lecturer at The University of the South Pacific; a Development leadership Programme (DLP) research associate; and an honorary research associate at the Institute of Human Security and Social Change (IHSSC), La Trobe University, Melbourne, Australia.

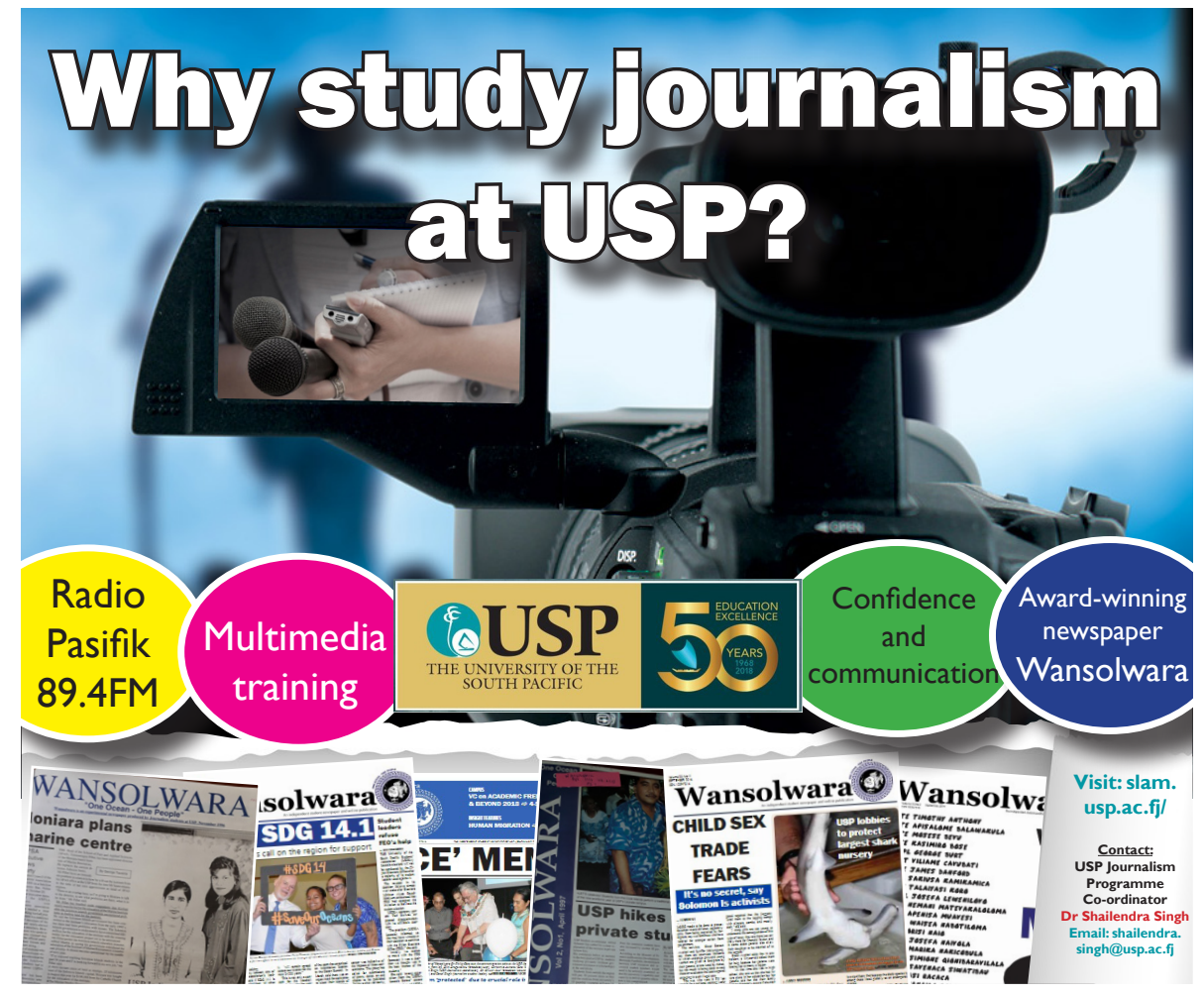

PACIFIC JOURNALISM REVIEW 24 (2) 201883 